\title{
HUBUNGAN PERILAKU DAN PERSONAL HIGYENE DENGAN INFEKSI CACINGAN PADA ANAK SD KELAS V DAN VI DI YAYASAN PERGURUAN ETIS LANDIA MEDAN
}

\author{
Endang Maryanti, Linda Hernike Napitupulu, Tebeziduhu Hulu \\ Program Studi Ilmu Kesehatan Masyarakat, Institut Kesehatan Helvetia \\ E-mail : endangmaryanti58@gmail.com
}

\begin{abstract}
Cumulatively infection of worms in children under five will cause losses in the form of calories, protein and blood will decrease nutrient status, this situation resulted in the child will be retan against other infectious diseases. The high prevalence of helminth infection in Grade V and VI Elementary School Foundation of Landis Medan Foundation makes this research necessary to be done. This study aims to determine the relationship between behavior and personal higyene with infection worms in elementary school children class V and VI Foundation of Etis Landia School of Medan. The type of this research design was analytic survey with data analysis used chi square test, the population amount in this research is 40 respondents by using sample from whole population, sample technique used total sampling. The result of this research showed that there is correlation between behavior with infectious infection with $\mathrm{p}=0,000<0,05$, and there is a significant correlation between personal higyene with infection of worms in elementary school children of class V and VI In Foundation of Etis Landia Medan Institute of 2017 with $p=0,000<0.05$. So it can be concluded that there is a relationship between behavior with infection infection and there is a relationship between personal higyene with infection of worms in elementary school children of class V and VI in Foundation of Ethics landia Medan Year 2017. It is recommended that the local health center to always monitor the health and infection of worms in primary school children. It is also expected for educators in schools to apply Clean and Healthy Behavior in the School environment and guide students to always maintain personal hygiene.
\end{abstract}

Keywords : Infection of Wrath

\begin{abstract}
Abstrak
Secara kumulatif infeksi cacingan pada anak balita akan menyebabkan kerugian berupa kalori, protein dan darah akan menurunnya satus gizi, keadaan ini mengakibatkan anak akan retan terhadap penyakit infeksi lainnya. Tingginya prevalensi infeksi cacingan pada SD Kelas V dan VI Yayasan Perguruan Etis Landia Medan membuat penelitian ini perlu untuk dilakukan. Penelitian ini bertujuan untuk mengetahui hubungan perilaku dan personal higyene dengan infeksi cacingan pada anak SD kelas V dan VI Yayasan Perguruan Etis Landia Medan. Jenis dan rancangan penelitian yang digunakan dalam penelitian ini adalah survei analitik dengan analisis data menggunakan uji chi square, jumlah populasi dalam penelitian ini adalah 40 responden dengan menggunakan sampel dari keseluruhan populasi, teknik sampel yang digunakan adalah total sampling. Hasil penelitian menunjukkan adanya hubungan antara perilaku dengan infeksi cacingan dengan nilai $p=0,000<0,05$, dan ada hubungan yang signifikan antara personal higyene dengan infeksi cacingan pada anak SD kelas V dan VI Di Yayasan Perguruan Etis Landia Medan dengan nilai $p=0,000<0,05$. Maka dapat di simpulkan bahwa ada hubungan antara perilaku dengan infeksi cacingan dan ada hubungan antara personal higyene dengan infeksi cacingan pada anak SD kelas V dan VI diYayasan perguruan Etis landia Medan. Diharapkan Puskesmas setempat agar selalu melakukan pemantauan kesehatan dan infeksi cacingan pada anak Sekolah Dasar. Diharapkan juga bagi tenaga pendidik di sekolah agar menerapkan Perilaku Hidup Bersih dan Sehat di lingkungan Sekolah serta membimbing siswa-siswi untuk selalu menjaga kebersihan diri.

Kata Kunci : Infeksi Cacingan
\end{abstract}




\section{PENDAHULUAN}

Derajat kesehatan masyarakat merupakan tolok ukur yang digunakan dalam pencapaian keberhasilan program dengan berbagai upaya berkesinambungan, terpadu dan lintas sektor dalam rangka pelaksanaan kebijakan pembangunan di bidang kesehatan. Derajat kesehatan masyarakat dimaksud adalah meningkatnya umur harapan hidup, menurunnya angka kematian bayi, ibu dan anak, menurunnya angka kesakitan maupun angka kecacatan dan ketergantungan serta meningkatnya status gizi masyarakat.

Lingkungan yang tidak sehat dapat menyebabkan berbagai macam penyakit. Penyakit berbasis lingkungan masih merupakan masalah kesehatan terbesar masyarakat. Hal ini tercermin dari tingginya angka kejadian dan kunjungan penderita beberapa penyakit kesarana pelayanan kesehatan seperti: Tb paru, Tifoid, diare, DBD, keracunan makanan, cacingan, keracunan bahan kimia dan pestisida. (Soemirat. 2015)

Secara kumulatif infeksi cacingan pada anak balita akan menyebabkan kerugian berupa kalori, protein dan darah akan menurunya satus gizi, keadaan ini mengakibatkan anak akan retan terhadap penyakit infeksi lainnya. Jika keadaan ini berlangsung lama akan mengganggu pertumbuhan dan perkembangan anak. Beberapa penelitian membuktikan adanya hubungan antara kecacinagan dengan status gizi, bagi anak usia sekolah akan mengakibatkan menurunkan kesegaran jasmani, prestasi belajar dan tingkat kehadiran disekolah

Berdasarkan penelitian Hidayat tahun 2014 pada Murid SD di Mataram menemukan prevalensi cacingan tidak kurang dari 93\% dengan infeksi cacing tunggal $17.84 \%$, campuran dua jenis cacing 81,89, 151 anak SD di temukan $69.5 \%$ positif telur cacing usus yang di tularkan melalui tanah. (Soemirat. 2015)

Berdasarkan data profil Dinas Kesehatan Sumatera Utara tahun 2015, prevalensi cacingan di kota Medan masih berada diangka 29,2\%. Dimana pelaksanaan program pengendalian masalah cacingan masih menargetkan untuk menurunkan prevalensi cacingan menjadi $<10 \%$ tahun 2015. Secara khusus di kota Medan, belum ada data mengenai prevalensi cacingan, apalagi pada anak balita (Dinas Kesehatan Provinsi Sumut 2015). Cacingan masih menjadi penyakit yang kurang mendapat perhatian (neglected disease) yaitu sekelompok penyakit menular yang tidak menyebabkan kematian secara langsung (WHO, 2015). Selain itu, sarana dari program pengendalian masalah cacingan diprioritaskan pada beberapa komponen penduduk, namun sampai saat ini kelompok anak sekolah dasar yang terjangkau, sedangkan untuk balita data cacingan masih belum menjadi prioritas.(DinkesSU, 2015)

Anak SD merupakan kelompok yang berada dalam periode kritis dalam masa pertumbuhan dan perkembangannya. Oleh karna itu akan terjadi resiko yang sangat besar bila pada kelompok ini terjadi infeksi cacingan (WHO, 2015). Menurut WHO anak SD adalah salah satu kelompok masyarakat yang beresiko untuk menderita cacingan sebab pada usia ini anak belum bisa secara mandiri mengurus personal hygienenya. Salah satu penularan cacing Ascaris Lumbrikoides dan Trichuristrichiura dapat terjadi apabila anak menelan larva infektif yang melekat di jaritangan pada waktu anak mengisap jari atau tidak mencuci tangan sebelum makan. Kejadian ini sering terjadi terutama pada anak yang sering bermain dan kontak dengan tanah yang tercemar telur cacing. Selain itu penularan juga dapat terjadi apabila anak memakan makanan atau memasukkkan mainan kedalam mulutnya yang telah dihinggapi lalat atau kecoa yang telah mengandung telur infektif setelah kontak dengan tanah atau feces manusia yang mengandung telur cacing. (Soemirat. 2015)

Tingginya prevalensi infeksi cacingan terutama disebabkan adanya beberapa faktor yang memberatkan terjadinya infeksi, seperti indonesia terletak di daerah beriklim tropis dan lembab, keadaan hygiene dan sanitasi yang kurang memenuhi syarat kesehatan, keadaan sosial 
ekonomi dan pendidikan yang belum memadai serta kepadatan penduduk. Faktor lain yang menyebabkan infeksi cacingan juga di pengaruhi oleh tingkat pengetahuan dan perilaku hidup sehat dari keluarga, yang berkaitan dengan higyene perorangan dan sanitasi lingkunan dan makanan, khususnya penggunaan air bersih, penggunaan jamban keluaraga, penggunaan alas kaki dan lainlain.

Berdasarkan survei awal yang telah dilakukan peneliti di SD Yayasan Perguruan Etis Landia Medan. Dari 10 siswa yang diwawancarai secara langsung terdapat 7 siswa yang tidak mengetahui mengenai perilaku dan personal hygiene terhadap infeksi cacingan, hal tersebut menyebabkan mereka kebanyakan berperilaku yang dapat menimbulkan infeksi cacingan seperti tidak mencuci tangan dengan sabun setelah buang air besar, tidak membersihkan dan memotong kuku secara teratur, tidak menjaga kebersihan bajunya, tidak menjaga kebersihan sekolah serta kebiasaan siswa membuka alas kaki saat berada di lingkungan sekolah.

\section{METODE PENELITIAN}

Penelitian ini dilakukan di SD Yayasan Perguruan Etis Landia, penelitian ini peneliti menggunakan metode survei analitik, yaitu peneliti yang mencoba menggali bagaimana dan mengapa fenomena itu terjadi. Kemudian melakukan analisis dinamika kolerasi antara fenomena, baik antara faktor resiko dan faktor efek. Dengan pendekatan bedah lintang (cross sectional) yaitu sampel diambil dari seluruh populasi.

HASIL PENELITIAN

Distribusi Frekuensi Responden Berdasarkan Umur pada Anak SD Kelas V dan VI di Yayasan Perguruan Etis Landia Medan

\begin{tabular}{ccc}
\hline & Frekuensi & Persentase \\
\cline { 2 - 3 } Umur & $\mathbf{n}$ & $\mathbf{\%}$ \\
& 21 & 52,5 \\
11 & 18 & 45,0 \\
12 & 1 & 2,5 \\
13 & $\mathbf{4 0}$ & $\mathbf{1 0 0 , 0}$ \\
\hline Total & &
\end{tabular}

Berdasarkan tabel diatas dapat diketahui bahwa dari 40 responden, mayoritas yang memiliki umur 11 tahun sebanyak 21 responden (52,5\%), yang memiliki umur 12 tahun sebanyak 18 responden $(45,0 \%)$ dan yang minoritas memiliki umur 13 tahun sebanyak 1 responden $(2,5 \%)$.

Distribusi Frekuensi Responden Berdasarkan Jenis kelamin pada Anak SD Kelas V dan VI di Yayasan Perguruan Etis Landia Medan

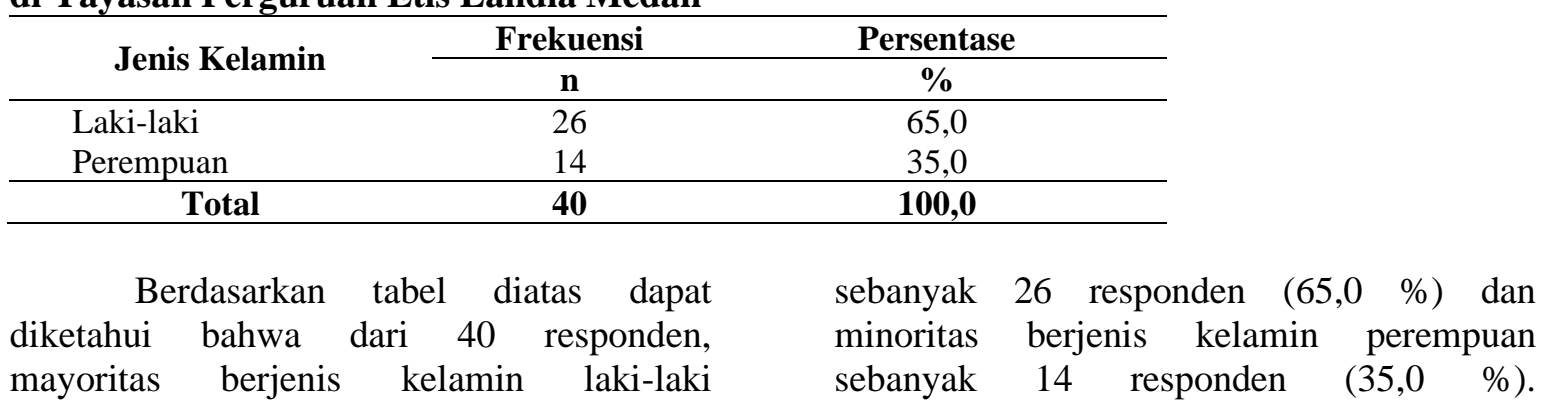


Distribusi Frekuensi Responden Berdasarkan Perilaku pada Anak SD Kelas V dan VI di Yayasan Perguruan Etis Landia Medan

\begin{tabular}{lcc}
\hline \multirow{2}{*}{ Perilaku } & Frekuensi & Persentase \\
\cline { 2 - 3 } & $\mathbf{n}$ & \% \\
\hline Baik & 15 & 37,5 \\
Kurang & 25 & 62,5 \\
\hline \multicolumn{1}{c}{ Total } & $\mathbf{4 0}$ & $\mathbf{1 0 0 , 0}$ \\
\hline
\end{tabular}

Berdasarkan tabel diatas dapat responden $(62,5 \%)$ dan minoritas perilaku diketahui bahwa dari 40 responden, baik sebanyak 25 responden $(37,5 \%)$.

mayoritas Perilaku kurang sebanyak 15

Distribusi Frekuensi Responden Berdasarkan Personal Higyene pada Anak SD Kelas V dan VI di Yayasan Perguruan Etis Landia Medan

\begin{tabular}{lcc}
\hline \multirow{2}{*}{ Personal Hiygene } & Frekuensi & Persentase \\
\cline { 2 - 3 } & $\mathbf{n}$ & $\mathbf{\%}$ \\
\hline Baik & 15 & 37,5 \\
Kurang & 25 & 62.5 \\
\hline \multicolumn{1}{c}{ Total } & $\mathbf{4 0}$ & $\mathbf{1 0 0 , 0}$ \\
\hline
\end{tabular}

Berdasarkan tabel diatas dapat diketahui bahwa dari 40 responden, mayoritas berpesonal hiygene yang kurang sebanyak 15 responden $(62,5 \%)$ dan minoritas berpesonal hygene baik sebanyak 25 responden $(37,5 \%)$.

Distribusi Frekuensi Responden Berdasarkan Infeksi cacingan pada Anak SD Kelas V dan VI di Yayasan Perguruan Etis Landia Medan

\begin{tabular}{ccc}
\hline \multirow{2}{*}{ Infeksi Cacingan } & Frekuensi & Persentase \\
\cline { 2 - 3 } & $\mathbf{n}$ & $\mathbf{\%}$ \\
\hline Positif cacingan & 15 & 37,5 \\
Negatif cacingan & 25 & 62,5 \\
\hline Total & $\mathbf{4 0}$ & $\mathbf{1 0 0 , 0}$ \\
\hline
\end{tabular}

Berdasarkan tabel diatas diatas dapat diketahui bahwa dari 40 responden, mayoritas negatif cacingan sebanyak 25 responden $(62,5 \%)$ dan minoritas positif cacingan sebanyak 15 responden $(37,5 \%)$.

Tabulasi Silang Hubungan Perilaku dengan Infeksi Cacingan pada Anak SD Kelas V dan VI di Yayasan Perguruan Etis Landia Medan

\begin{tabular}{|c|c|c|c|c|c|c|c|}
\hline \multirow{3}{*}{ Perilaku } & \multicolumn{4}{|c|}{ Infeksi Cacingan } & \multirow{2}{*}{\multicolumn{2}{|c|}{ Total }} & \multirow{3}{*}{$p$} \\
\hline & \multicolumn{2}{|c|}{ Positif } & \multicolumn{2}{|c|}{ Negatif } & & & \\
\hline & $\mathbf{n}$ & $\%$ & $\mathbf{n}$ & $\%$ & $\mathbf{n}$ & $\%$ & \\
\hline Baik & 0 & 0,0 & 15 & 37,5 & 15 & 37,5 & \\
\hline Kurang & 15 & 37,5 & 10 & 25,0 & 25 & 62,5 & 0,000 \\
\hline Total & 15 & 37,5 & 25 & 62,5 & 40 & 100,0 & \\
\hline
\end{tabular}

Berdasarkan data tabulasi silang diatas diketahui bahwa dari 15 responden $(37,5 \%)$ yang memiliki perilaku baik dengan infeksi cacingan positif tidak ada dan perilaku baik dengan infeksi cacingan negatif sebanyak $15(37,5 \%)$. Dari 25 responden
$(62,5 \%)$ yang memiliki perilaku kurang dengan infeksi cacingan positif sebanyak 15 responden $(37,5 \%)$ dan yang memiliki perilaku kurang dengan infeksi cacingan negatif sebanyak 10 responden $(25,0 \%)$. Dari analisis diperoleh $p=0,000<\operatorname{sig} \alpha=0,05$. 
Tabulasi Silang Hubungan Personal Higyene dengan Infeksi Cacingan pada Anak SD Kelas V dan VI di Yayasan Perguruan Etis Landia Medan

\begin{tabular}{ccccccccc}
\hline \multirow{2}{*}{$\begin{array}{c}\text { Personal } \\
\text { Higyene }\end{array}$} & \multicolumn{4}{c}{ Infeksi Cacingan } & \multicolumn{2}{c}{ Total } & \multirow{2}{*}{$\boldsymbol{p}$} \\
\cline { 2 - 6 } & \multicolumn{3}{c}{ Positif } & \multicolumn{2}{c}{ Negatif } & & \\
\hline Baik & 0 & $\mathbf{\%}$ & f & \% & f & \% & \\
Kurang & 15 & 37,0 & 15 & 37,5 & 15 & 37,5 & \\
\hline Total & $\mathbf{1 5}$ & $\mathbf{3 7 , 5}$ & $\mathbf{2 5}$ & $\mathbf{6 2 , 5}$ & $\mathbf{4 0}$ & $\mathbf{1 0 0 , 0}$ & \\
\hline
\end{tabular}

Berdasarkan data tabulasi silang diatas diketahui bahwa dari 15 responden $(37,5 \%)$ yang memiliki personal higyene baik dengan infeksi cacingan positif tidak ada dan personal higyene baik dengan infeksi cacingan negatif sebanyak $15(37,5 \%)$. Dari 25 responden $(62,5 \%)$ yang memiliki personal higyene kurang dengan infeksi cacingan positif sebanyak 15 responden $(37,5 \%)$ dan yang memiliki personal higyene kurang dengan infeksi cacingan negatif sebanyak 10 responden $(25,0)$. Dari hasil analisis diperoleh nilai $p 0,000<\operatorname{sig} \alpha=$ 0,05 .

\section{PEMBAHASAN}

Hasil penelitian secara statistik menunjukkan nilai $p=0,000<\alpha=0,05$. Berarti ada hubungan antara perilaku dengan infeksi cacingan pada anak SD kelas V dan VI di Yayasan perguruan Etis Landia .

Sesuai dengan Penelitian yang dilakukan oleh Rawina Winita tahun 2012 mengenai Upaya Pemberantasan Cacingan SD, hasil penelitian menunjukkan angka infeksi sebelum edukasi adalah 11,5\% dengan spesies Ascaris lumbricoides, Trichuris trichiuraserta infeksi campur A. Lumbricoides dan Trichuris trichiura. Enam bulan setelah edukasi angka infeksi turun bermakna menjadi $0,9 \%(p=0,002)$ dengan jenis infeksi campur A. Lumbricoides dan T. trichiura. (Kartini, 2016)

Perilaku sehat pada dasarnya adalah respon seseorang terhadap stimulus yang berkaitan dengan sakit dan penyakit, sistem pelayanan kesehatan makanan serta lingkungan.sebagai contoh perilaku yang berkaitan dengan lingkungan, misalnya perilaku seseorang dengan pembuangan air kotor yang menyangkut segi -segi higyene, pemeliharaan, teknik dan penggunaannya. Perilaku sehat dipengaruhi oleh berbagai hal seperti :

1. Latar belakang seseorang yang memiliki norma-norma yang ada, kebiasaan, nilai budaya dan keadaan sosial ekonomi, yang berlaku di masyarakat.

2. Kepercayaan meliputi manfaat yang akan di dapat, hambatan yang ada, kerugian, dan kepercayaan bahwa seseorang dapat terserang penyakit.

3. Sarana merupakan tersedia atau tidaknya fasilitas yang dapat dimanfaatkan oleh masyarakat.

Perilaku kesehatan dapat dirumuskan sebagai segala bentuk pengalaman dan interaksi individu dengan lingkungannya, khusu yang menyangkut pengetahuan dan sikap tentang kesehatan. Salah satu aspek yang penting dalam penanggulangan infeksi cacingan adalah dengan cara meningkatakna pengetahuan dan perilaku keluarga tentang hygiene perorangan serta sanitasi lingkungan dan makanan meliputi : Mandi pakai sabun 2 kali sehari, memotong dan membersihkan kuku, cuci tangan sebelum makan dan sehabis buang air besar di jamban yang memenuhi syarat, menjaga kebersihan lingkungan rumah tangga serta menggunakan alat bersih.

Berdasarkan asumsi peneliti dari hasil penelitian ini, bahwa perilaku siswasiswi masih tergolong kurang dalam menjaga kebersihan diri ini menyebabkan terjadinya infeksi cacingan, hal ini terbukti masih banyaknya siswa-siswi yang tidak menyadari bahwa mencuci tangan menggunakan sabun setelah bermain maupun buang air besar merupakan hal yang sangat penting dalam mencegah terjdinya infeksi cacingan. Untuk itu diharapkan perlu dilakukan tindakan- 
tindakan pencegahan seperti melakukan penyuluhan maupun menyiapkan fasilitas penunjang seperti tempat mencuci tangan bagi siswa-siswi di lingkungan sekolah dan tenaga pengajar diharapkan ikut serta dalam memantau kebersihan siswa-siswi seperti memotong kuku, selalu menggunakan alas kaki dilingkungan sekolah dan memantau siswa-siswi pada saat bermain bersama teman-temannya. Menurut Hasibuan (2019) didalam mencapai suatu tujuan perlu diberikan pendidikan yang merupakan sebuah proses pembelajaran dari sebuah pengetahuan, keterampilan, sikap dan perilaku.

\section{Hubungan Personal Higyene dengan Infeksi Cacingan pada Anak SD Kelas V dan VI di Yayasan Perguruan Etis Landia Medan}

Hasil penelitian secara statistik menunjukkan nilai $p=0,000<\alpha=0,05$. Berarti ada hubungan antara personal higyene dengan infeksi cacingan pada anak SD kelas V dan VI di Yayasan perguruan Etis Landia

Berarti ada hubungan antara personal higyene dengan infeksi cacingan pada anak SD kelas V dan VI di Yayasan Perguruan Etis Landia . Hal ini sesuai dengan penelitian Sri Kartini tahun 2016 mengenai Kejadian Cacingan pada Siswa SDN di Kecamatan Rumbai Pesisir Pekanbaru, hasil penelitian diperoleh proporsi cacingan 16,3\%, jenis Ascaris lumbricoides 13,0\%, Trichuiris trichiura 2,5\% dan cacing Tambang $0,8 \%$.Variabel yang berhubungan dengan cacingan: minum obat cacing (POR:11,143; 95\%CI: 4,179(31,886), kebiasaan mencuci tangan (POR:5,366; 95\%CI: 2,186 (13,172), ketersediaan SPAL (POR : 2,615; 95\% CI: 1,195(6,787), kebersihan kuku (POR : 2,378; $95 \%$ CI : 1,300 (7,227).

Hygiene adalah usaha kesehatan masyarakat yang mempelajari pengaruh kondisi lingkungan terhadap kesehatan manusia, upaya mencegah timbulnya penyakit karena pengaruh lingkungan kesehatan tersebut, serta membuat kondisi lingkungan yang sedemikian rupa hingga terjamin pemeliharaan kesehatan .

Kebersihan diri atau hygiene perorangan yang buruk merupakan cerminan dari kondisi lingkungan atau perilaku individu yang sehat. Penduduk miskin dengan kebersihan diri yang buruk mempunyai kemungkinan lebih besar untuk terinfeksi oleh semua jenis cacing.

Dari hasil beberapa penelitian pengaruh infeksi cacingan dengan kecerdasan, di ketahui bahwa infeksi cacingan dapat menurunkan kesehatan jasmani, pertumbuhan dan selera makan pada anak yang terinfeksi Ascaris lumbricoides dan trichuris trichiura. Penyakit ini tidak menyebabkan orang mati secara mendadak, tetapi menyebabkan penderita semakin lemah karena kehilangan darah yang menahun sehingga menurunkan daya tahan tubuh dan memperberat penyakit lainnya sehingga pada saat tertentu akan menurunkan prestasi dan produktivitas.

Berdasarkan asumsi peneliti dari hasil penelitian ini, bahwa personal higyene yang kurang baik menyebabkan seseorang mengalami infeksi cacingan, seperti halnya kurang memperhatikan kebersihan diri. Kebersihan itu sendiri sangat dipengaruhi oleh nilai individu dan kebiasaan. Hal-hal yang sangat berpengaruh itu diantaranya kebudayaan, sosial, keluarga, pendidikan dan persepsi seseorang terhadap kesehatan. Masih banyaknya siswa-siswi yang tidak memahami akan efek dari hal tersebut menyebabkan masalah infeksi cacingan menjadi masalah kesehatan yang harus segera di selesaikan karena akan menjadi faktor pemicu masalahmasalah kesehatan yang baru misalnya menurunnya tingkat prestasi dan gizi kurang, diharapkan masalah infeksi cacingan bagi siswa-siswi segera diatasi oleh pihak terkait dalam hal ini Dinas Kesehatan setempat sehingga kejadian infeksi cacingan pada siswa-siswi khususnya anak SD Etis Landia dan pada umumnya wilayah Sumatera Utara tidak terjadi kembali di masa yang akan datang. 


\section{KESIMPULAN}

Berdasarkan penelitian yang dilakukan dan disajikan pada bab sebelumnya dapat disimpulkan antara bahwa Hasil uji chi square menunjukkan terdapat hubungan yang signifikan antara perilaku dengan infeksi cacingan pada anak SD Kelas V dan VII di Yayasan Perguruan Etis Landia dengan nilai $p=0,000<0,05$ dan Hasil uji chi square menunjukkan terdapat hubungan yang signifikan antara personal higyene dengan infeksi cacingan pada anak SD Kelas V dan VI di Yayasan Perguruan Etis Landia dengan nilai $p=0,000<0,05$.

\section{SARAN}

Bagi pihak sekolah diharapkan selalu berkoordinasi kepada petugas kesehatan setempat untuk dapat diberikan pemeriksaan kesehatan secara berkala dalam memaksimalkan status kesehatan peserta didiknya.

\section{REFERENSI}

Dinas Kesehatan. (2015). Profil kesehatan provinsi sumatera utara kota medan.

Hasibuan, M, T, D. (2019). Hubungan stres belajar dengan motivasi belajar pada mahasiswa yang menjalani pendidikan di sekolah tinggi ilmu kesehatan murni teguh. Indonesian Trust Health Journal, Vol.2, No.1, Agustus 2019.

Kartini, S. (2016). Kejadian cacingan pada siswa sd negeri kecamatan rumbai pekan baru. Jurnal Kesehatan Komunitas, Vol 3.,No. 2 Mei.

Soemirat, S. (2015). Epidemiologi lingkungan. Gadjah Mada University Pres. Yogyakarta.

Soemirat, S. (2015). Kesehatan Lingkungan. Gadjah Mada University Pres. Yogyakarta. 